\title{
Prevention of experimentally induced whirling disease in rainbow trout Oncorhynchus mykiss by Fumagillin
}

\author{
M. El-Matbouli, R. W. Hoffmann \\ Institute of Zoology and Hydrobiology, University of Munich, Kaulbachstraße 37, 8000 München 22, Germany
}

\begin{abstract}
Feeding of Fumagillin DCH salt could prevent clinical outbreak of whirling disease in experimentally infected rainbow trout Oncorhynchus mykiss fry. Whereas 73.3 to $100 \%$ of nonmedicated fish in 2 experimental series had severe infections, only 10 to $20 \%$ of medicated trouts harbored Myxobolus cerebralis spores to a very low degree. In contrast to those from non-medicated fish, $M$. cerebralis spores from Fumagillin-treated trouts had distinct morphological defects. Fumagillin seems to be an effective orally administrable drug for the control of whirling disease in salmonid fish.
\end{abstract}

\section{INTRODUCTION}

Salmonid whirling disease is an important and serious disease of farm-reared salmonids, especially of rainbow trout in Europe and North America. Heavy infections may cause severe deformation of the skull and backbone, and damage around the auditory organ may lead to the whirling symptom (Hoffman 1962). It was earlier generally accepted that infectivity for fish develops endogenously in the spores of Myxobolus cerebralis. The only way to avoid whirling disease was therefore through management actions and the radical disinfection of contaminated ponds (Hoffman 1962, Halliday 1976). Markiw \& Wolf (1983), however, found that development of infectivity of $M$. cerebralis for fish was an exogenous process, in which a tubificid oligochaete played an essential role. Subsequently the life cycle was described and illustrated by Wolf \& Markiw (1984) and El-Matbouli \& Hoffmann (1989). To date, no efficacious drugs against salmonid whirling disease have been found, although some therapeutics such as Acetarsol (Scolari 1954) and Furazolidone (Taylor et al. 1973) have been tested. Later Proguanil hydrochloride and Clamoxyquin were studied by Aldeman (1986), but further tests are needed to confirm the efficacy of these drugs. Recently, the relatively longknown antibiotic Fumagillin was shown to be effective against renal sphaerosporosis in carp (Molnar et al. 1987 ) and proliferative kidney disease (PKD) in sal- monid fish (Hedrick et al. 1988). The present paper shows that Fumagillin is also able to control whirling disease by oral administration.

\section{MATERIAL AND METHODS}

\section{Experiment 1.}

Experimental infection of rainbow trout fry: $100 \mathrm{~g}$ of actinosporea-free tubificids (about 90\% Tubifex tubifex) from our own SPF culture were kept in a 201 aerated glass aquarium. The bottom was covered with a $5 \mathrm{~cm}$ layer of sterilized sand; the water temperature was 16 to $17^{\circ} \mathrm{C}$. The tubificids were exposed to viable Myxobolus cerebralis spores, as described earlier (ElMatbouli \& Hoffmann 1989). First waterborne Triactinomyxon spores were detected at about Day 90 postexposure. At Day 120 squash preparations revealed that tubificids were heavily infected with Triactinomyxon. The tubificids were isolated, cleaned by cautious washing and then transferred to small capsules covered by a net with $300 \mu \mathrm{m}$ mesh. The capsule was transferred to a $100 \mathrm{l}$ glass aquarium containing 60 rainbow trout fry (mean weight $4 \mathrm{~g}$ ) of our whirling disease free SPF stock. The day of first contact was regarded as day of infection. At Day 14 post-infection (pi), the capsule containing tubificids was removed; at Day 30 pi the rainbow trout were divided into 2 groups of 30 , kept separately in two 501 tanks. A control 
consisted of two $50 \mathrm{Itanks,}$ in which 2 groups of $30 \mathrm{SPF}$ rainbow trout fry from the same population were placed. Fish were fed commercial pelleted fish food ( $1.0 \%$ of body weight per day).

Treatment: Beginning from Day 30 pi until the end of the experiment (160 d pi), one group of the experimentally infected fish and one control group were fed on medicated pellets $(1.0 \%$ of body weight per day), containing $0.1 \%$ of Fumagillin in the form of the dicyclohexylamine (DCH), manufactured by Chinoin Pharmaceutical and Chemical Works Ltd (Hungary). The chemical name is 2,4,6,8-decatetraenedioic acid (4(1,2-epoxy-1,5-dimethyl)-5-methoxy-1-oxaspiro(2.5)oct6 -yl) monoester. The other groups received normal diets.

The fish wore checlicd daily for clinical signs. For detection of Myxobolus cerebralis infection, heads of fish that had died or were killed were divided sagitally into 2 parts. The skull skeleton from one of the halves was squashed and examined under a light microscope. The severity of infection with $M$. cerebralis spores was estimated on an arbitrary scale between negative $(-)$, low infection with single spores in several fields of vision $(+)$, medium infection with 2 to 5 spores per field of vision $(++)$ and severe infection with masses of spores per field of vision $(+++)$ using a $40 \times$ objective. The other half of the skull, as well as liver, kidney, spleen, intestine, pancreas, brain and gills, was fixed in $5 \%$ buffered formalin and embedded in Parablast ${ }^{\mathrm{R}}$ and Historesin ${ }^{R}$ for histological examination. Sections $5 \mu \mathrm{m}$ thick were stained with haematoxylin and eosin ( $H \& E$ ) and Giemsa. Small pieces of infected cartilage were fixed in phosphate-buffered $6.25 \%$ glutaraldehyde for 3 to $4 \mathrm{~h}$, post-fixed in $1 \% \mathrm{OsO}_{4}$ for $2 \mathrm{~h}$, dehydrated in graded acetone series and embedded in Epon 812. Semi-thin sections were stained with toluidine blue.

Experiment 2. In this experiment the same procedure as in Expt 1 was followed except that feeding of medicated diet was started earlier, at $14 \mathrm{~d} \mathrm{pi}$, and lasted for only $50 \mathrm{~d}$ instead of $130 \mathrm{~d}$

\section{RESULTS}

\section{Experiment 1}

Rainbow trout fed on Fumagillin-medicated pellets did not show any whirling movement or black tails. At $136 \mathrm{~d}$ pi, 22 fish were killed, and in 4 of these low degrees of infection with Myxobolus cerebralis were found. Two further fish were found infected (1 in a low. 1 in a medium degree) at the end of the observation time at Day $160 \mathrm{pi}$. In summary, $6(20 \%)$ out of 30 fish were positive. In both squash preparations and histological slides, the spores had an unusual appearance. Very often one or both polar capsules were lacking. The spore wall was often irregularly deformed and shrunken, indicating an affection of capsular cells (Fig. 1). Due to the destructive alterations it was often difficult to identify them as $M$. cerebralis spores.

In non-medicated fish, 5 individuals developed clinical signs of whirling disease at Day 92 pi. Up to Day 105 pi the number of clinically affected fish increased to 18 . On autopsy at Day 136 pi, all 18 affected fish could be shown to be severely infected. The spores were morphologically intact and were found in large amounts in destroyed parts of head cartilage (Fig. 2). At the end of the experiment, at Day 160 pi, a further 4 out of 10 clinically healthy trout harboured a medium degree of infection. In total, $22(73.3 \%)$ out of 30 non-medicated fish were infected (Table 1).

\section{Experiment 2}

In non-medicated fish, 22 showed whirling movement and black tails at Days 48 to 56 pi and died within $7 \mathrm{~d}$. Histological examination of these fish indicated severe infection with trophozoites of Myxobolus cerebralis in cranial cartilage. The remaining 8 trout also developed whirling movements and black tails and

Table 1. Oncorhynchus mykiss. Rainbow trout fry infected experimentally with whirling disease. Effect of Fumagillin DCH at a concentration of $1.0 \mathrm{~g}$ per $\mathrm{kg}$ diet fed from $30 \mathrm{~d}$ pi for $130 \mathrm{~d}$

\begin{tabular}{|c|c|c|c|c|c|c|}
\hline \multirow[t]{2}{*}{ Day pi } & \multicolumn{3}{|c|}{$\begin{array}{l}\text { Medicated diet } \\
\text { Fish with }\end{array}$} & \multicolumn{3}{|c|}{$\begin{array}{l}\text { Non-medicated diet } \\
\text { Fish with }\end{array}$} \\
\hline & $\mathrm{n}$ & $\begin{array}{l}\text { clinical } \\
\text { signs }\end{array}$ & $\begin{array}{l}\text { M. cerebralis } \\
\text { spores (degree } \\
\text { of infection) }\end{array}$ & $\mathrm{n}$ & $\begin{array}{c}\text { clinical } \\
\text { signs }\end{array}$ & $\begin{array}{l}\text { M. cerebralis } \\
\text { spores (degree } \\
\text { of infection) }\end{array}$ \\
\hline $47-50$ & - & & & {$[2]^{a}$} & - & - \\
\hline 136 & $22[4]$ & - & $4+$ & 18 & 18 & $18++t$ \\
\hline 160 & 8 & - & $2+$ & 10 & - & $4++$ \\
\hline Total & 30 & - & $6(20 \%)$ & 30 & $18(60 \%)$ & $22(73.3 \%)$ \\
\hline Dead fish & & & & & & \\
\hline
\end{tabular}



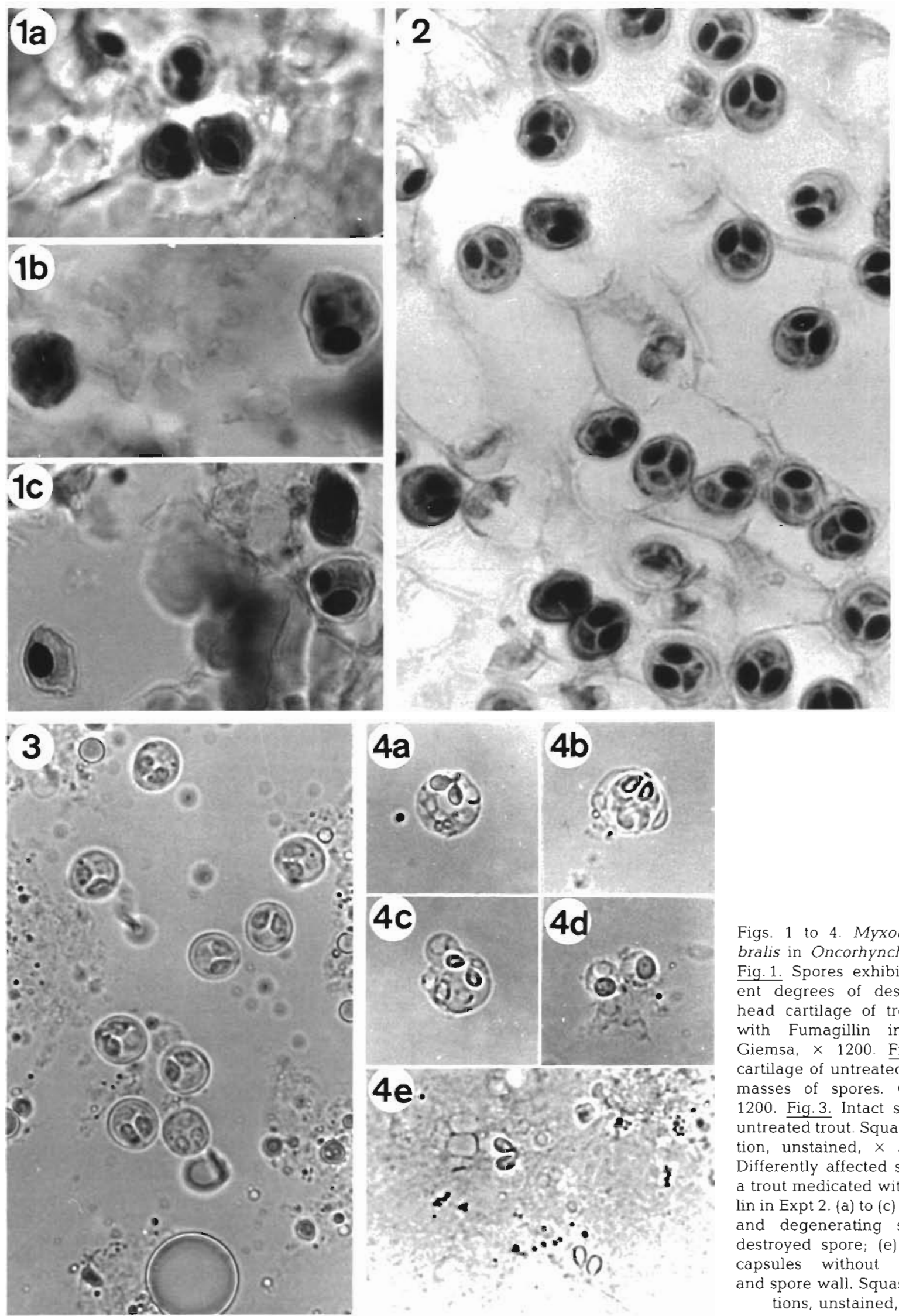

$4 a$
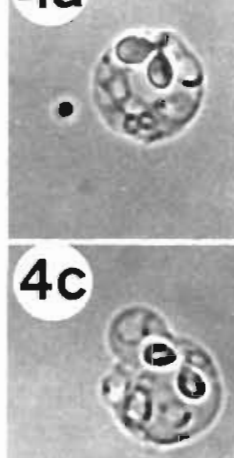

$4 d$
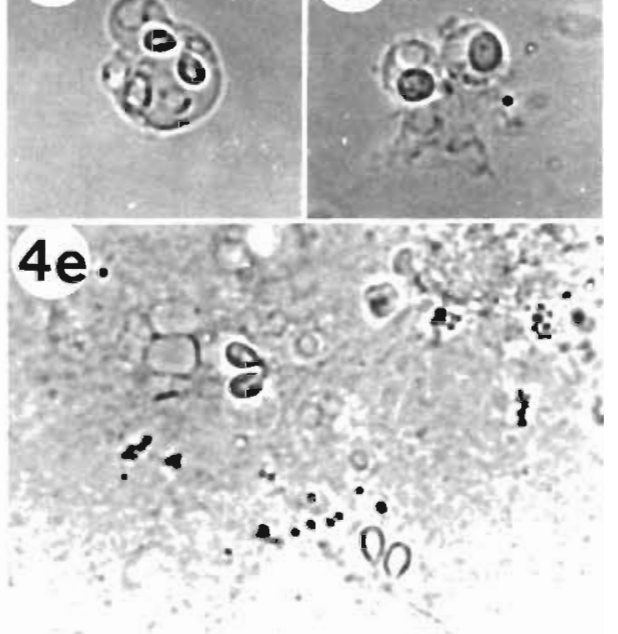

Figs. 1 to 4. Myxobolus cerebralis in Oncorhynchus mykiss. Fig. 1. Spores exhibiting different degrees of destruction in head cartilage of trout treated with Fumagillin in Expt 1. Giemsa, $\times$ 1200. Fig. 2. Head cartilage of untreated trout with masses of spores. Giemsa, $x$ 1200. Fig. 3. Intact spores from untreated trout. Squash preparation, unstained, $\times$ 590. Fig. 4. Differently affected spores from a trout medicated with Fumagillin in Expt 2. (a) to (c) Vacuolized and degenerating spores; (d) destroyed spore; (e) free polar capsules without sporoplasm and spore wall. Squash preparations, unstained $\times 590$ 
histologically and in fresh mounts of cranial cartilages showed severe infection with $M$. cerebralis spores (Fig. 3).

One fish of the medicated trials showed clinical signs $104 \mathrm{~d}$ pi. Squash preparation and histological examination of this fish and 2 other without clinical signs showed a very low degree of infection with Myxobolus cerebralis. However most spores were extremely deformed and destroyed, one or both polar capsules often being free without surrounding sporoplasm or spore wall (Fig. 4). Table 2 summarises the results of Expt 2.

In both experiments, histological examination of liver, spleen, kidney, intestine, pancreas, gills and bran of medicated fish (infected and non-infected) did not show any pathological changes and were nut discennible from those of infected fish and uninfected controls fed non-medicated diet.

\section{DISCUSSION}

The experiments show that Fumagillin is able to prevent clinical outbreaks of whirling disease under laboratory conditions. Furthermore the infection rate and the severity of sporulation could be reduced drastically from $73.3 \%$ in the first experiment and $100 \%$ in the second, mostly severely infected, to $20 \%$ and $10 \%$ respectively infected to a low degree. This trend is in full agreement with results for renal sphaerosporosis (Molnar et al. 1987) and PKD (Hedrick et al. 1988) as well as for microsporean infection of the Japanese eel (Kano \& Fukui 1982).

Although the mode of action of Fumagillin is not known, the reduction of spore numbers, as well as the changes of the morphology of spores visible in the light microscope, suggests an effect on DNA or RNA synthesis (Hartwig \& Przelecka 1971, Jaronski 1972) or on the spore wall (Liu 1973). Further studies in this field are in preparation. It is furthermore open to question whether the spores in the skulls of medicated trout are still viable and infective. The morphologically visible destruction may support the contrary. The localisation in cartilages may be because these apparently defective spores are not removed by natural defense mechanisms, since there is no or only slight contact to blood cells. This is in contrast to renal sphaerosporosis and PKD, where the parasites are in close contact with blood vessels and the immune system. These conditions may also explain the apparently 'better' effects of medication in sphaerosporosis and PKD, where no or only very few parasite stages could be detected in treated fish (Molnar et al. 1987. Hedrick et al. 1988).

The very long time (106 d) of drug administration in Expt 1 may harbour some risks for the fish. Even if no toxic effects could be demonstrated in our rainbow trout, such effects were documented by Hedrick et al. (1988) in chinook salmon and rainbow trout. Drug administration beginning at Day 30 after a first possible contact with the parasite in the first experiment is apparently not able to prevent the arrival of parasites in the target organ. In contrast, feeding of the drug $14 \mathrm{~d}$ pi in Expt 2 was found to reduce the severity of sporulation and the infection rate drastically from $100 \%$, mostly severely infected, to $10 \%$ mildly infected trout. Early administration of Fumagillin-diet may thus prevent the migrating stages of Myxobolus cerebralis. Further experiments with the same and lower dosages initiated immediately and after a few days from first contact of fish with waterborne Triactinomyxon spores are in preparation.

Table 2. Oncorhynchus mykiss. Rainbow trout fry infected experimentally with whirling disease. Effect of Fumagillin DCH at a concentration of $1.0 \mathrm{~g}$ per $\mathrm{kg}$ diet fed from $14 \mathrm{~d}$ pi for $50 \mathrm{~d}$

\begin{tabular}{|c|c|c|c|c|c|c|}
\hline \multirow[t]{2}{*}{ Day pi } & \multicolumn{3}{|c|}{$\begin{array}{l}\text { Medicated diet } \\
\text { Fish with }\end{array}$} & \multicolumn{3}{|c|}{$\begin{array}{l}\text { Non-medicated diet } \\
\text { Fish with }\end{array}$} \\
\hline & $\mathrm{n}$ & $\begin{array}{l}\text { clinical } \\
\text { signs }\end{array}$ & $\begin{array}{l}\text { M. cerebralis } \\
\text { spores (degree } \\
\text { of infection) }\end{array}$ & $\mathrm{n}$ & $\begin{array}{l}\text { clinical } \\
\text { signs }\end{array}$ & $\begin{array}{c}\text { M. cerebralis } \\
\text { spores (degree } \\
\text { of infection) }\end{array}$ \\
\hline $48-56$ & 2 & - & - & {$[22]^{a}$} & 22 & $\begin{array}{l}\text { Trophozoites of } \\
M \text {. cerebralis }\end{array}$ \\
\hline 90 & 2 & - & - & 2 & 2 & ++ \\
\hline 104 & 2 & 1 & $\begin{array}{l}\text { Damaged spores } \\
\text { of } M . \text { cerebralis }\end{array}$ & 2 & 2 & +++ \\
\hline 118 & 2 & - & - & 2 & 2 & +++ \\
\hline 132 & 2 & - & 1 damaged spore & 2 & 2 & +++ \\
\hline 160 & 20 & - & 1 damaged spore & & & \\
\hline Total & 30 & $1(3 \%)$ & $3(10 \%)$ & 30 & $30(100 \%)$ & $30(100 ")$. \\
\hline
\end{tabular}


Regarding safety for the human consumer, the depuration time for the drug, between ossification of the skull and slaughter, is more than a year and would seem to offer sufficient security (Hedrick et al. 1988). But here also more experiments regarding metabolism and excretion of Fumagillin in fish will be necessary before the drug can be used in the field.

Acknowledgements. This work was supported by the German Research Foundation (Grant No DFG HO645/8-1). Our thanks go to Dr Peter Sarközy (Chinoin, Budapest) for encouraging the experiments and supplying us with Fumagillin.

\section{LITERATURE CITED}

Aldermann, D. J. (1986). Whirling disease chemotherapy. Bull. Eur. Ass. Fish Pathol. 6 (2): 38-40

El-Matbouli, M., Hoffmann, R. (1989). Experimental transmission of two Myxobolus spp. developing bisporogeny via tubificid worms. Parasitol. Res. 75: 461-464

Halliday, M. M. (1976). The biology of Myxosoma cerebralis: the causative organism of whirling disease of salmonids. J. Fish Biol. 9: 339-357

Hartwig, A., Przelecka, A. (1971). Nucleic acids in intestine of Apis mellifica infected with Nosema apis and treated with Fumagillin DCH: cytochemical and autoradiographic studies. J. Invertebr. Pathol. 18: 331-336

Responsible Subject Editor: W. Korting, Hannover, Germany
Hedrick, R. P. Groff, J. M., Foley, P., McDowell, T. (1988). Oral administration of Fumagillin DCH protects chinook salmon Oncorhynchus tshawytscha from experimentally induced proliferative kidney disease. Dis. aquat. Org. 4: $165-168$

Hoffman, G. L. (1962). Whirling disease of trout. U.S. Department of the Interior Fishery Leaflet 508: 1-3

Jaronski, S. T (1972). Cytochemical evidence for RNA synthesis inhibition by Fumagillin. J. Antibiotics 25 (6): 327-331

Kano, T., Fukui, H. (1982). Studies on Pleistophora infection in eel. Anguilla japonica I. Experimental induction of microsporosis and Fumagillin efficacy. Fish Pathol. 16: 193-200

Liu, T. P. (1973). Effects of Fumidil B on the spore of Nosema apis and on lipids of the host cell as revealed by freezeetching. J. Invertebr. Pathol. 22: 364-368

Markiw, M. E., Wolf, K. (1983). Myxosoma cerebralis (Myxozoa, Myxosporea) etiologic agent of salmonid whirling disease requires tubificid worms (Annelida: Oligochaeta) in its life cycle. J. Protozool. 30: 561-564

Molnar, K., Baska, F. Szekely, Cs. (1987). Fumagillin, an efficacious drug against renal sphaerosporosis of the common carp Cyprinus carpio. Dis. aquat. Org. 2: 187-190

Scolari, C. (1954). Sull'impiego dello Stovarsole nella profilassi del 'capostorno' o 'lentosporiasi' delle trote d'allevamento. Clin. veterin. $77(2)$ : $50-53$

Taylor, E. N., Coh, S. J., Innen, B. R. (1973). Attempts to control whirling disease by continuous drug feeding. J. Wildl. Dis. 9: 302-305

Wolf, K., Markiw, M. E. (1984). Biology contravenes taxonomy in the Myxozoa: new discoveries show alternation of invertebrate and vertebrate host. Science 225: 1449-1452

Manuscript first received: December 10, 1990

Revised version accepted: January 22, 1991 